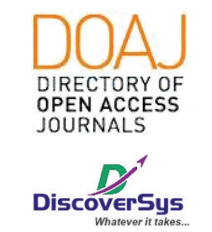

Published by DiscoverSys

\section{Hubungan suami perokok terhadap bayi berat lahir rendah pada neonatus di ruang Perinatologi RSUD Wangaya kota Denpasar}

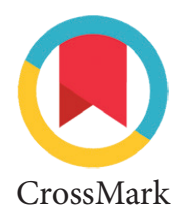

\author{
William Grandinata Soeseno, ${ }^{*}$ I Wayan Bikin Suryawan, A.A. Made Widiasa
}

\title{
ABSTRACT
}

Background: Low birth weight babies (LBW) are still a problem. The causes of LBW are multifactorial, one of which is exposure to toxic substances (cigarettes). Exposure to cigarette smoke can disrupt fetal development during the womb. Based on studies, active and passive smokers have almost the same level of risk. This study aimed to find out about a smoker's husband as a risk factor for the occurrence of low birth weight babies in neonates at Perinatology Room of Wangaya Hospital, Denpasar.

Methods: Analytical observational research with case-contro/ research design. The study sample was all neonates who were treated in the Perinatology Room of Wangaya Hospital from May to August 2018 and fulfilled the inclusion and exclusion criteria. Based on the calculation of the sample size, 72 neonates were obtained. The sample is determined by consecutive sampling. In this study, data were obtained from medical records (documentation) and questionnaires.

Result: Samples were divided into two groups, namely the case group and controls where each group consisted of 36 samples. As many as 23 of the 36 neonates who were smokers' husbands suffered from low birth weight babies $(63.88 \%)$, while 13 others did not suffer from low birth weight babies (36.11\%). The results of hypothesis testing using the chisquare test, the value of $p=0.03(p<0,05,0 R=2,78, C l=0,091-0,267)$. Conclusion: Smokers' husbands were significantly a risk factor for the occurrence of low birth weight babies in neonates who were treated in the Perinatology room of Wangaya Hospital, Denpasar.

Keywords: LBW, smoking husband

Cite This Article: Soeseno, W.G., Suryawan, I.W.B., Widiasa, A.A.M. 2019. Hubungan suami perokok terhadap bayi berat lahir rendah pada neonatus di ruang Perinatologi RSUD Wangaya kota Denpasar. Intisari Sains Medis 10(1): 139-143. D0I: 10.1556/ism.v10i1.399

\section{ABSTRAK}

Latar Belakang: Bayi Berat Lahir Rendah (BBLR) masih merupakan masalah. Penyebab BBLR adalah multifaktor, salah satunya paparan zat toksis (rokok). Paparan asap rokok dapat mengakibatkan gangguan perkembangan janin selama dalam kandungan. Berdasarkan studi, perokok aktif dan pasif memiliki tingkat resiko yang hampir sama. Penelitian ini bertujuan untuk mencari tahu suami perokok merupakan faktor risiko terjadinya bayi berat lahir rendah pada neonatus di ruang Perinatologi RSUD Wangaya Kota Denpasar.

Metode: Penelitian observasional analitik dengan rancangan penelitian case control. Sampel penelitian adalah seluruh neonatus yang dirawat di ruang Perinatologi RSUD Wangaya sejak bulan Mei sampai Agustus 2018 serta memenuhi kriteria inklusi dan ekslusi. Berdasarkan perhitungan besar sampel maka diperoleh 72 neonatus. Sampel ditentukan dengan cara consequtive sampling. Dalam penelitian ini, data diperoleh dari rekam medis (dokumentasi) dan kuisioner.

Hasil: Sampel berjumlah 72 sampel. Sampel dibagi menjadi dua kelompok yaitu kelompok kasus dan kontrol dimana masing-masing kelompok terdiri dari 36 sampel. Sebanyak 23 dari 36 neonatus yang merupakan bayi dari suami perokok menderita bayi berat lahir rendah (63,88\%), sedangkan 13 lainnya tidak menderita bayi berat lahir rendah (36,11\%). Hasil uji hipotesis dengan menggunakan uji chi square, didapatkan nilai $\mathrm{p}=0,03(\mathrm{p}<0,05, \mathrm{R}=2,78, \mathrm{Cl}=0,091$ 0,267

Simpulan: Suami perokok secara signifikan merupakan faktor resiko terhadap terjadinya bayi berat lahir rendah pada neonatus yang dirawat di ruang Perinatologi RSUD Wangaya Kota Denpasar.
Bagian/SMF IImu Kesehatan Anak RSUD Wangaya, Bali-Indonesia

*Corresponding:

William Grandinata Soeseno,

Bagian/SMF IImu Kesehatan Anak

RSUD Wangaya, Bali-Indonesia

williamgrandinata@gmail.com

Received: 2019-01-17

Accepted: 2019-02-04

Published: 2019-04-01

\section{Kata kunci: BBLR, suami perokok}

Cite Pasal Ini: Soeseno, W.G., Suryawan, I.W.B., Widiasa, A.A.M. 2019. Hubungan suami perokok terhadap bayi berat lahir rendah pada neonatus di ruang Perinatologi RSUD Wangaya kota Denpasar. Intisari Sains Medis 10(1): 139-143. D0I: 10.1556/ism.v10i1.399

\section{PENDAHULUAN}

Bayi Berat Lahir Rendah (BBLR) adalah bayi dengan berat lahir kurang dari 2500 gram tanpa memandang usia gestasi. Bayi berat lahir rendah masih merupakan masalah diseluruh dunia, karena menjadi salah satu penyebab utama kesakitan dan kematian pada neonatal. ${ }^{1}$ Target Milleneum Development Goals (MDGs) sampai dengan tahun 2015 adalah mengurangi angka kematian bayi dan 
balita sebesar dua per tiga dari tahun 1990 yaitu sebesar 20 per 1000 kelahiran hidup. Dari data Survey Demografi Kesehatan Indonesia (SDKI) dari tahun 2003 turun menjadi 35 per 1000 kelahiran hidup, dan pada tahun 2007 sudah turun menjadi 34 per 1000 kelahiran hidup. ${ }^{2}$

Angka kejadian Bayi Berat Lahir Rendah (BBLR) di Negara berkembang relatif masih tinggi. Angka tersebut bervariasi di setiap daerah. Hasil riset kesehatan 2007, menyinpulkan bahwa kejadian BBLR secara proporsional untuk tingkat nasional mencapai 15\%. Hasil studi 3 wilayah, presentase kejadian BBLR terendah di Propinsi Bali sebesar $5,8 \%$, tertinggi di propinsi Papua sebesar 27,0\% dan Sulawesi Selatan mencapai 1,36\%.,3

Faktor penyebab BBLR sampai saat ini masih terus dikaji. Beberapa studi menyebutkan penyebab BBLR adalah multifaktor, antara lain faktor demografi, biologi ibu, gizi, riwayat obstetri, morbiditas ibu selama hamil, periksa hamil (prenatal care) dan paparan zat toksis (merokok).,4,5

Perilaku yang buruk selama kehamilan seperti paparan asap rokok dapat mempengaruhi suplai oksigen dari tubuh ibu ke janin dan plasenta. Paparan asap rokok juga dapat menurunkan kadar asam folat ibu yang berakibat terganggunya pertumbuhan janin di dalam kandungan..$^{3,4}$

Asap rokok terdiri dari 4000 bahan kimia dan 200 diantaranya beracun, antara lain Karbon Monoksida (CO) yang dihasilkan oleh asap rokok dan dapat menyebabkan pembuluh darah kramp, sehingga tekanan darah naik, dinding pembuluh darah dapat robek. Gas CO dapat pula menimbulkan desaturasi hemoglobin, menurunkan langsung peredaran oksigen untuk jaringan seluruh tubuh termasuk miokard. CO menggantikan tempat oksigen di hemoglobin, mengganggu pelepasan oksigen, dan mempercepat aterosklerosis (pengapuran atau penebalan dinding pembuluh darah). Nikotin juga merangsang peningkatan tekanan darah. Nikotin mengaktifkan trombosit dengan akibat timbulnya adhesi trombosit (pengumpalan) ke dinding pembuluh darah. Nikotin, $\mathrm{CO}$ dan bahan lainnya dalam asap rokok terbukti merusak dinding pembuluh endotel (dinding dalam pembuluh darah), mempermudah pengumpalan darah sehingga dapat merusak pembuluh darah perifer. ${ }^{5,6}$

Radikal bebas akan merusak tiga komponen molekul utama dari sel tubuh yaitu lipid, protein dan DNA. Kerusakan pada lipid disetiap oksidasi dan pada proses dasar oksidasi DNA sel akan mengganggu integritas sel, sehingga akan menimbulkan kematian sel. ${ }^{7}$

Data yang dihimpun selama tiga tahun terakhir oleh Stephen G. Grant, peneliti kesehatan lingkungan di Universitas Pittsburgh, menunjukkan bahwa wanita yang menjadi perokok pasif melahirkan bayi yang mengalami mutasi genetik atau sama halnya wanita perokok. Menurutnya perokok pasif memiliki pengaruh buruk bagi janin. Hasil penelitiannya ini dimuat dalam online jurnal BMC Pediatric.

Semakin jelas bahwa merokok tidak hanya berpengaruh pada orang yang menghisapnya, namun juga mempengaruhi semua orang disekitarnya, termasuk janin yang sedang berkembang yang ibunya kebetulan berada di dekat orang yang merokok. $^{2,5}$

\section{METODE}

Penelitian ini merupakan penelitian analitik observasional dengan desain case control untuk menelaah hubungan antara efek (penyakit atau kondisi kesehatan) tertentu dengan faktor risiko tertentu. Penelitian ini dilakukan di ruang perinatologi RSUD Wangaya Kota Denpasar sejak bulan Mei 2018.

Sampel penelitian adalah seluruh pasien neonatus yang dirawat di ruang Perinatologi RSUD Wangaya Kota Denpasar sejak bulan Mei 2018 serta memenuhi kriteria inklusi dan eksklusi. Besar sampel mínimum pada penelitian ini adalah 72 sampel yang terdiri dari 36 kasus (Bayi Berat Lahir Rendah (BBLR)) dan 36 kontrol (Bayi Berat Lahir Normal). Sampel dipilih menggunakan teknik consecutive sampling. Kriteria inklusi adalah pasien neonatus (0-28 hari) yang dirawat di ruang Perinatologi RSUD Wangaya Kota Denpasar sejak Mei 2018, pasien yang orang tuanya bersedia berpartisipasi dalam penelitian dan menandatangani informed consent. Kriteria ekslusi adalah neonatus yang dilahirkan dari ibu perokok aktif, neonatus yang dilahirkan dari ibu yang menderita Ketuban Pecah Dini (KPD), neonatus yang dilahirkan dari ibu yang menderita Preeklampsia/eklampsia dan hipertensi gravidarum, neonatus dengan kelainan plasenta.

Sumber data dalam penelitian ini adalah berupa data primer dengan menggunakan kuisioner, data sekunder yang berasal dari rakam medis pasien. Kuisioner yang digunakan adalah lembar yang berisi karakteristik responden yang meliputi identitas, kuantitas dan kualitas dari banyaknya suami merokok, berat badan bayi baru lahir di Ruang Kaswari RSUD Wangaya. Persetujuan penelitian dan penggunaan rekam medis telah disetujui oleh Kepala bagian SMF Anak di RSUD Wangaya Denpasar.

Variabel bebas pada penelitian ini adalah suami perokok, variabel terikat adalah Bayi Berat Lahir Rendah (BBLR). Penelitian ini dilakukan analisis univariat untuk mendeskripsikan karakteristik responden. Analisis bivariat dilakukan untuk menghubungkan antara variabel bebas dengan variabel 
terikat dengan menggunakan uji Chi Square dengan tingkat kemaknaan 5\% $(\alpha=0,05)$. Besarnya risiko suami perokok terhadap kejadian bayi berat lahir rendah dinyatakan dalam ratio (RO) dengan interval kepercayaan 95\%. Data diolah dengan Statistical Product and Service Solution (SPSS) 23 for Windows.

\section{HASIL}

Usia kehamilan pada kasus lebih banyak yang kurang bulan atau preterm $22(61,1 \%)$. Sampel penelitian ini dikelompokkan menjadi dua yaitu kasus dan kontrol. Jenis kelamin paling banyak yang mengalami bayi berat lahir rendah adalah laki-laki 19 (52,8\%). Riwayat persalinan pada sampel bayi berat lahir rendah didominasi oleh persalinan spontan atau normal $24(66,7 \%)$ (Tabel 1).

23 dari 36 neonatus yang menderita bayi berat lahir rendah dengan suami perokok $(63,88 \%)$, sedangkan 13 lainnya tidak menderita bayi berat lahir rendah $(36,11 \%)$. Tabel 2 memperlihatkan hasil uji hipotesis dengan menggunakan uji chi square, dimana didapatkan nilai $\mathrm{p}$ sebesar 0,03 . Karena nilai $\mathrm{p}<0,05$, maka dapat disimpulkan bahwa terdapat hubungan yang signifikan antara suami perokok dengan kejadian bayi berat lahir rendah pada neonatus.

Hubungan antara suami perokok dengan terjadinya bayi berat lahir rendah pada neonatus disajikan dalam risiko prevalensi (RO), dengan rumus sebagai berikut:

Tabel 1 Karakteristik sampel

\begin{tabular}{lcc}
\hline \multicolumn{1}{c}{ Variabel } & $\begin{array}{c}\text { Kasus (\%) } \\
(\mathbf{n = 3 6 )}\end{array}$ & $\begin{array}{c}\text { Kontrol (\%) } \\
(\mathbf{n = 5 0 4 )}\end{array}$ \\
\hline Jenis Kelamin (\%) & & \\
Laki-laki & $19(52,8)$ & $20(55,6)$ \\
Perempuan & $17(42,2)$ & $16(44,4)$ \\
Usia Kehamilan (\%) & & $10(27,8)$ \\
Preterm & $22(61,1)$ & $26(72,2)$ \\
Aterm & $14(38,9)$ & $13(36,1)$ \\
Riwayat Persalinan (\%) & & $23(63,9)$ \\
Normal & $24(66,7)$ & \\
Sectio Caesarea & $12(33,3)$ & \\
\hline
\end{tabular}

Tabel 2 Hubungan Suami Perokok dengan Bayi Berat Lahir Rendah

\begin{tabular}{lccccc}
\hline \multirow{2}{*}{ Variabel } & \multicolumn{2}{c}{ BBLR } & & & \\
\cline { 2 - 3 } & Ya & Tidak & Total & RO (IK 95\%) & P-Value \\
\hline Suami perokok & & & & & \\
Ya & 23 & 13 & 36 & $2,78(0,091-0,267)$ & $0,03^{*}$ \\
Tidak & 14 & 22 & 36 & & \\
Total & 37 & 35 & 72 & & \\
\hline
\end{tabular}

* Uji Chi Square

$$
\begin{aligned}
\mathrm{RO} & =\frac{\mathrm{a} /(\mathrm{a}+\mathrm{c}): \mathrm{c} /(\mathrm{a}+\mathrm{c})}{\mathrm{b} /(\mathrm{b}+\mathrm{d}): \mathrm{d} /(\mathrm{b}+\mathrm{d})} \\
& =\frac{\mathrm{a} / \mathrm{c}}{\mathrm{b} / \mathrm{d}}=\frac{\mathrm{ad}}{\mathrm{bc}} \\
& =\frac{23 \times 22}{13 \times 14}=2,78
\end{aligned}
$$

Keterangan:

$$
\begin{array}{ll}
a /(a+c) & : \text { Proporsi kasus dengan risiko. } \\
c /(c+d) & : \text { Proporsi kontrol dengan risiko. } \\
b /(b+d) & \text { : Proporsi kasus tanpa risiko. } \\
d /(b+d) & : \text { Proporsi kontrol tanpa risiko. }
\end{array}
$$

Interpretasi hasil:

$\mathrm{RO}<1$ : Suami perokok merupakan faktor protektif terjadinya bayi berat lahir rendah.

$\mathrm{RO}=1$ : Suami perokok bukan merupakan faktor atau tidak berpengaruh terhadap terjadinya bayi berat lahir rendah.

RO $>1$ : Suami perokok benar-benar merupakan faktor risiko atau berpengaruh terhadap terjadinya bayi berat lahir rendah.

Dari hasil perhitungan didapatkan risiko odds sebesar 2,78, dimana dapat diinterpretasikan bahwa suami perokok merupakan faktor risiko terhadap terjadinya bayi berat lahir rendah pada neonatus sebesar 2,78 kali. Interval kepercayaan 95\% sebesar 0,091-0,267, dimana tidak mencakup angka 1 , yang berarti dalam populasi hal tersebut di atas benar terjadi. Suami perokok secara signifikan merupakan faktor resiko terhadap terjadinya bayi berat lahir rendah pada neonatus.

\section{DISKUSI}

Karakteristik sampel pada penelitian ini antara lain jenis kelamin, usia kehamilan, riwayat persalinan. Keseluruhan sampel berjumlah 72 neonatus yang di kelompokkan menjadi dua yaitu kelompok kasus dan kontrol yang masing-masing kelompok terdiri dari 36 sampel.

Bayi berat lahir rendah (BBLR) paling banyak pada ibu dengan usia kehamilan kurang bulan atau preterm $(61,1 \%)$. Hasil penelitian ini memiliki kesamaan dengan hasil penelitian Rahmi pada tahun 2013 di RSIA Pertiwi Makasar, yang memaparkan proporsi penderita bayi berat lahir rendah berdasarkan usia kahamilan yaitu 70,63\%. Bayi berat lahir rendah sering ditemukan pada neonatus yang di lahirkan dari ibu yang memiliki usia kehamilan kurang bulan yaitu kurang dari 37 minggu. $^{8}$ Usia kehamilan merupakan salah satu faktor risiko terjadinya bayi berat lahir rendah. ${ }^{9}$ 
Hasil riset kesehatan 2007, menyimpulkan bahwa kejadian BBLR secara proporsional untuk tingkat nasional mencapai $15 \%$. Hasil studi 3 wilayah, presentase kejadian BBLR terendah di Propinsi Bali sebesar 5,8\%, tertinggi di propinsi Papua sebesar 27,0\% dan Sulawesi Selatan mencapai $1,36 \%{ }^{5}$

Faktor penyebab BBLR sampai saat ini masih terus dikaji. Beberapa studi menyebutkan penyebab BBLR adalah multifaktor, antara lain faktor demografi, biologi ibu, gizi, riwayat obstetri, morbiditas ibu selama hamil, periksa hamil (prenatal care) dan paparan toksis (merokok). Perilaku yang buruk selama kehamilan seperti paparan asap rokok dapat mempengaruhi suplai oksigen dari tubuh ibu ke janin dan plasenta. Paparan asap rokok juga dapat menurunkan kadar asam folat ibu yang berakibat terganggunya pertumbuhan janin di dalam kandungan. ${ }^{10-15}$

Asap rokok terdiri dari 4000 bahan kimia dan 200 diantaranya beracun, antara lain Karbon Monoksida (CO) yang dihasilkan oleh asap rokok dan dapat menyebabkan pembuluh darah kramp, sehingga tekanan darah naik, dinding pembuluh darah dapat robek. Gas CO dapat pula menimbulkan desaturasi hemoglobin, menurunkan langsung peredaran oksigen untuk jaringan seluruh tubuh termasuk miokard. CO menggantikan tempat oksigen di hemoglobin, mengganggu pelepasan oksigen, dan mempercepat aterosklerosis (pengapuran atau penebalan dinding pembuluh darah). Nikotin juga merangsang peningkatan tekanan darah. Nikotin mengaktifkan trombosit dengan akibat timbulnya adhesi trombosit (pengumpalan) ke dinding pembuluh darah. Nikotin, CO dan bahan lainnya dalam asap rokok terbukti merusak dinding pembuluh endotel (dinding dalam pembuluh darah), mempermudah pengumpalan darah sehingga dapat merusak pembuluh darah perifer. ${ }^{10-15}$

Radikal bebas akan merusak tiga komponen molekul utama dari sel tubuh yaitu lipid, protein dan DNA. Kerusakan pada lipid disetiap oksidasi dan pada proses dasar oksidasi DNA sel akan mengganggu integritas sel, sehingga akan menimbulkan kematian sel. Oleh karena adanya paparan asap rokok mengakibatkan terjadinya bayi berat lahir rendah..$^{10,11}$

Penelitian ini dilakukan untuk megetahui suami perokok merupakan faktor risiko terjadinya bayi berat lahir rendah pada neonatus. Dari hasil penelitian ini didapatkan nilai p sebesar 0,03 . Karena nilai $\mathrm{p}<0,05$, maka dapat disimpulkan bahwa terdapat hubungan yang signifikan antara suami perokok dengan bayi berat lahir rendah pada neonatus. Dari hasil perhitungan didapatkan risiko odds yaitu
2,78. Hal ini berarti suami perokok merupakan faktor risiko terhadap terjadinya bayi berat lahir rendah pada neonatus sebesar 2,78 kali. Interval kepercayaan 95\% sebesar 0,091-0,267 dimana tidak mencakup angka 1, yang berarti dalam populasi hal tersebut di atas benar terjadi. Hasil penelitian ini serupa dengan penelitian yang dilakukan oleh Nurlaila (2013) yang menyimpulkan bahwa terdapat hubungan yang signifikan antara suami perokok dengan bayi berat lahir rendah. ${ }^{16}$

\section{KETERBATASAN}

Kelemahan pada penelitian ini antara lain, data dalam penelitian ini masih menggunakan data sekunder dan pada penelitian ini variabel independen yang diteliti hanya terbatas pada suami perokok, sehingga beberapa faktor risiko lain dalam pustaka yang kemungkinan berhubungan dengan variabel dependen tidak dianalisis. Faktor risiko yang menyebabkan terjadinya bayi berat lahir rendah sangatlah bervariasi. Oleh karena itu perlu dilakukan penelitian lebih lanjut mengenai faktor risiko yang berhubungan dengan bayi berat lahir rendah, dengan cakupan populasi terjangkau yang lebih luas. Selain itu subyek dalam penelitian kurang variatif karena hanya mengambil dari satu rumah sakit sehingga tidak bisa digeneralisasikan serta waktu dalam pengumpulan sampel yang cukup singkat.

\section{SIMPULAN}

Pasien bayi berat lahir rendah pada neonatus di ruang Perinatologi RSUD Wangaya lebih banyak pada ibu dengan usia kehamilan yang muda atau preterm dan dengan persalinan normal. Terdapat hubungan yang signifikan antara suami perokok dengan kejadian bayi berat lahir rendah pada pasien neonatus yang dirawat di ruang Perinatologi RSUD Wangaya Kota Denpasar.

\section{DAFTAR PUSTAKA}

1. Pudjiadi AH, Hegar B, Handryastuti S, Idris NS, Gandaputra EP, Harmoniati ED (Eds). Pedoman Pelayanan Medis Ikatan Dokter Anak Indonesia. Jakarta: IDAI. 2009:428-431.

2. Departemen Kesehatan RI. Pencapaian Indonesia sehat di tahun 2001.In: Pusat data kesehatan Departemen Kesehatan Indonesia, editor. Profil kesehatan Indonesia 2001. Jakarta: Departemen Kesehatan Republik Indonesia. 2002. p. 29-34.

3. WHO Press. Neonatal and perinatal mortality: country, regional and global estimates. Geneva: WHO. 2006. P. iii-iv.

4. Kementrian Kesehatan Republik Indonesia. Data dan informasi (Profil Kesehatan Indonesia). Departemen Kesehatan RI, Jakarta. 2013. 
5. Riset Kesehatan Dasar (RISKESDAS). Badan Penelitian dan Pengembangan Kesehatan, Kementerian Kesehatan Republik Indonesia. Laporan Nasional. Jakarta: 2013;1-384.

6. Departemen Kesehatan RI. Pedoman teknis pelayanan kesehatan dasar pelayanan kesehatan neonatal esensial. Jakarta: Departemen Kesehatan RI. 2000; p. 1-13.

7. Rohsiswatmo R, Dewanto NEF, Dewi F. Bayi berat lahir rendah. Dalam: Pudjiadi AH, Hegar B, Handryastuti S, Idris NH, Gandaputra EP, Harmoniati, ED, editor. Pedoman Pelayanan Medis IDAI. Jakarta. PP IDAI. 2010.h.23-29.

8. Rahmi DSA, Rismayanti. Faktor - Faktor yang Berhubungan dengan Kejadian Bayi Berat Badan Lahir Rendah di RSIA Pertiwi Makasar. 2013.

9. Kardana, I. Risk Factors of Perinatal Asphyxia in The Term Newborn at Sanglah General Hospital, Bali-Indonesia. Bali Medical Journal. 2016. 5(1): 175-178. DOI:10.15562/bmj. v5i1.312

10. Ringer SA. Care of The Extremely Low Birth Weight Infant. Dalam: Cloherty JP, Eichenwald EC, Stark AR, ed. Manual of Neonatal Care. Edisi ke-6. Philadelphia: Lippincott Williams dan Wilkins. 2008.h.78-85.

11. Papageorgiou A, Pelausa E, Kovacs L. The Extremely Low Birth Weight Infant. Dalam: MacDonald MG, Seshia MMK, Mullet MD. Avery's Neonatology. Pathophysiolgy and Management of The Newborn. Edisi k-6. Philadelphia. Lippincott Williams and Wilkins. 2005. h.459-489.
12. Djelantik IG.G. In: editors. Program penyesuaian metode kanguru di rumah sakit (in hospital kangoroo adaptation). Proceedings of the Perinatal Workshop and International Symposium of PERINASIA "Pelatihan perawatan metode kanguru". 2001 Oktober 18-19; Bali. Bali: Perkumpulan Perinatologi Indonesia (Perinasi); 2001. $4^{\text {th }}$ book p. 1-15.

13. Roudbari M, et al. Prevalence and Risk Factors of Low Birth-Weight Infants in Zahedan, Islamic Republic of Iran, La Revue De Santé De La Mediterranee Orientale. 2007. Vol $13 \mathrm{~N} 4$

14. Ahman E, Zupan J. Neonatal and perinatal mortality: Country, regional and global estimates. Geneva: World Health Organization, Department of Making Pregnancy Safer. 2007. p.1-2

15. Jehan I, Harris H, Salat S, Zeb A, Mobeen N, Pasha O, et al. Neonatal mortality, risk factors and causes: a prospective population-based cohort study in urban Pakistan. Bull World Health Organ. 2009; 87:130-8.

16. Nurlaila R. Hubungan Ibu Hamil Perokok Pasif dengan Kejadian Bayi Berat Badan Lahir Rendah di Badan Layanan Umum Daerah RSU Muraxa Banda Aceh. Jurnal Ilmiah STIKES U’Budiyah. 2012. 1(2).

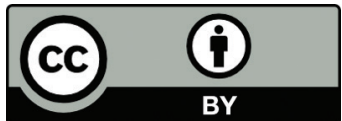

This work is licensed under a Creative Commons Attribution 